\title{
Öğretmen ve Velilerin Gözünden Öğrencilerin Uzaktan Eğitime Katılımlarının Öyküleri: "Uzaktan Eğitim mi, Uzakta Kalan Eğitim mi?”*
}

\section{The Stories of Students' Participation in Distance Education from the Perspective of Teachers and Parents: "Distance Education or Distant Education?"}

\author{
Yücel KABAPINAR* (D), Büşra Melis KANYILMAZ iD, Nihan ÖREN KOÇHAN iD, Uğur ATİK (D)
}

\section{öz}

$\mathrm{Bu}$ araştırmada, sınıf öğretmenlerinin ve velilerinin gözünden öğrencilerin uzaktan eğitim sürecine katılamama nedenlerine ve süreç boyunca yaşananlara yönelik görüşlerinin değerlendirilmesi amaçlanmıştır. Araştırma nitel bir araştırma olup durum çalışması desenine sahiptir. Araştırmanın çalışma grubunu; 2020-2021 eğitim-öğretim yılında, ilkokullarda görev yapan 36 sınıf öğretmeni ile ilkokul kademesinde öğrenim gören çocuğu bulunan 18 veli oluşturmaktadır. Araştırma verilerinin toplanmasında çevrimiçi anket formu ve yarı yapılandırılmış görüşme formu kullanılmıştır. Öncelikle katılımcı sınıf öğretmenler ve veliler, araştırmacılar tarafından hazırlanan çevrimiçi anket formunu doldurmuşlardır. Ardından 18 katılımcı veli arasından seçilen üç veli ve 36 katılımcı öğretmen arasından seçilen üç öğretmen ile görüşmeler gerçekleştirilmiştir. Elde edilen veriler içerik analizi kullanılarak analiz edilmiştir. Araştırma sonuçları öğrencilerin uzaktan eğitim sürecine; internet, teknolojik altyapı ve donanım eksikliği, ailelerin gereken ilgi ve desteği göstermemesi gibi nedenlerle katılamadığını ortaya koymaktadır. Öğretmenlerin bu süreçte, uzaktan eğitime katılamayan öğrenciler için yaygın olarak sosyal iletişim uygulamalarından ve yardımcı kaynaklardan ödevlendirmeler yaptığı, video çekip gönderdiği ve telefonla ders anlattığı belirlenmiştir. Uzaktan eğitim sürecine katılamayan öğrenciler için sınıf öğretmenleri ve velilerin duygu ve düşünceleri benzerlik göstermektedir. Öğretmen ve veliler sürece yönelik olarak üzüldüklerini, kaygı duyduklarını ve çaresiz hissettiklerini belirtmişlerdir. Sınıf öğretmenleri, uzaktan eğitime katılamayan öğrenciler için ailelerden ilgili ve bilinçli olmalarını; devletten internet, teknolojik donanım ve altyapı desteğinin sağlanmasını beklemektedirler.

Anahtar Kelimeler: Covid-19, temel eğitim, uzaktan eğitim, firsat eşitliği

\begin{abstract}
In this study, it was aimed to evaluate students' opinions about the reasons for not participating in the distance education process and what happened during the process from the perspective of classroom teachers and parents. The research is a qualitative research and has a case study design. The study group of the research; in the 2020-2021 academic year, it consists of 36 classroom teachers working in primary schools and 18 parents with children studying at the primary school level. An online questionnaire and semi-structured interview form were used to collect research data. First of all, participating classroom teachers and parents filled out the online questionnaire prepared by the researchers. Then, interviews were conducted with three teachers selected from among 18 participating parents and 36 participating teachers. The obtained data were analyzed using content analysis. The results of the research are based on the distance education process of students; It reveals that they could not attend due to the lack of internet, technological infrastructure and equipment, families not showing the necessary interest and support. In this process, it was determined that teachers who could not participate in distance education commonly made homework from social communication applications and auxiliary sources, shot and sent videos and gave lectures by phone. For students who cannot participate in the distance education process, the feelings and thoughts of classroom teachers and parents are similar. Teachers and parents stated that they feel sorry, anxious and helpless about the process. Classroom teachers need parents to be interested and aware of students who cannot participate in distance education; they expect internet, technological equipment and infrastructure support from the state.
\end{abstract}

Keywords: Covid-19, primary education, distance education, equality in opportunity

* Bu araştırmaya araştırmacılar eşit katkıda bulunmuşlardır. İsimler alfabetik olarak sıralanmıştır. “*Marmara Üniversitesi Atatürk Eğitim Fakültesi Temel Eğitim Bölümü

Sorumlu Yazar/Correspondence Author: Yücel KABAPINAR

E-posta/E-mail: ykabapinar@marmara.edu.tr

Geliş Tarihi/Received: 16.04.2021

Kabul Tarihi/Accepted: 24.05.2021

Ç. Yayınlanma Tarihi/Online Published: 31.05.2021 


\section{GİRIş}

2019 yılının Aralık ayının bundan sonra yazılacak tarih kitaplarında insanlık için önemli bir dönüm noktası olarak nitelendirileceği aşikârdır. Bunun nedeni Çin’in Wuhan kentinde ilk kez görülen Koronavirüs (Covid-19) salgınıdır. Bu kentte görülmesinin ardından hızla yayılarak birkaç ay içerisinde tüm dünyada etkisini göstermiş ve küresel bir sorun olarak insanlığı tehdit eden bir durum halini almıştır. İnsan hayatını ciddi biçimde tehdit etmesi ve ölümlere sebep olması nedeniyle 11 Mart 2020'de Dünya Sağlık Örgütü (WHO) tarafından Covid-19, dünya çapında salgın olarak ilan edilmiştir. Covid-19 solunum yolu belirtileriyle birlikte ateş, öksürük, nefes darlı̆ğ gibi semptomlarla gelişen bir hastalıktır (Sağlık Bakanlığı, 2020a). Koronavirüs kaynaklı olarak, Şubat 2021 tarihi itibariyle yaklaşık olarak Türkiyede iki buçuk milyon vaka ve 27 bin vefat, dünya genelinde ise 100 milyon vaka ve iki milyon vefat olduğu tespit edilmiştir (WHO, 2021, s. 1).

Koronavirüs salgın, insan hayatının her alanını olumsuz etkilemiştir. Önemli ölçüde etkilenen alanlardan biri de eğitimdir. Eğitim çevreleri yüzyıllar içerisinde birçok yeni araç ve teknoloji ile desteklense de temelde sınıf, eğitim programı ve öğretmen üçlüsü büyük ölçüde değişime uğramadan eğitimde temel paydaş olarak yerini korumuştur. Son yıllarda bilişim teknolojilerindeki hızlı gelişmelerle, teknoloji de eğitimin önemli bir parçası olmaya başlamıştır. Koronavirüs salgını sebebiyle uzaktan eğitim uygulamalarına geçilmesi, bu süreci hızlandırarak eğitimde teknoloji kullanımını artırmıştır (Sezgin ve Fırat, 2020, s. 5).

Uzaktan eğitim; fırsat eşitsizliğine çözüm getiren, isteyen bireylere yaşam boyu eğitim sağlayan, eğitim teknolojilerinden yararlanmaya dayalı öğrenme uygulamaları olarak ifade edilmektedir (Kaya, 2002, s. 9). Uzaktan eğitim; akademik açıdan öğrencilerin çalışmalarını sürdürebilmesi (Doğan ve Koçak, 2020, s. 121), sosyal ortamlarından kopmaması, zaman yönünden ekonomik olması (Fidan, 2020, s. 30), bireysel öğrenmeyi sağlaması, bireye öğrenme sorumluluğu kazandırması (Kaya, 2002, s. 20) yönünden avantajlar sağlamaktadır. Salgın nedeniyle dünya üzerinde 191 ülkede okullar kapatılmış, derslerin uzaktan eğitimle devam edilmesi kararı alınmıştır. Ancak ülkelerin salgın dönemindeki eğitim ihtiyaçları için yürütmüş olduğu uygulamalar, beklentiyi istenilen düzeyde karşlayamamıştır. Bunun temel nedeni uzaktan eğitimin gerçekleşmesi için gerekli olan teknolojik aletlere erişimin sınırlı olmasıdır. Dünya genelinde bir buçuk milyar öğrencinin, yüzde 55’inin (826 milyon) evinde bilgisayar, yüzde 43’ünün (645 milyon) ise internete erişimi bulunmamaktadır (Birleşmiş Milletler Eğitim, Bilim ve Kültür Örgütü [United Nations Educational, Scientific and Cultural Organization (UNESCO)], 2020a). Öğrencilerin yüzde 31’i (463 milyon) de uzaktan eğitime erişim sağlayamamaktadır (Birleşmiş Milletler Uluslararası Çocuklara Acil Yardım Fonu [United Nations International Children's Emergency Fund, (UNICEF)], 2020). 180 ülke ve bölgeyi kapsayan UNESCO projeksiyonları, 2020 yılında yaklaşık 24 milyon öğrencinin (okul öncesinden yükseköğretime kadar) okullar, üniversiteler veya diğer eğitim kurumları dâhil olmak üzere eğitim kurumlarına geri dönmeme riski altında olacağını tahmin etmektedir (UNESCO, 2020b).

Türkiye’de 16 Mart 2020 tarihinde okullar kapatılmış, 23 Mart 2020 tarihinden itibaren tüm seviyedeki sınıflarla uzaktan eğitime başlanmıştır. Bu süreçte eğitime, Millî Eğitim Bakanlığ1 [MEB] destekli Eğitimde Bilişim Ağı [EBA], TRT EBA TV, internette görüntülü ve sesli katılımı sağlayan uygulamalar ve okulların uzaktan eğitim sistemleri aracılığıyla devam edilmiştir. Uzaktan eğitime erişemeyen öğrenciler için de 14 bin 570 EBA Destek Noktası ve 175 Mobil Destek Noktası oluşturulmuştur. Kapsayıcı eğitim faaliyetlerine yönelik olarak da EBA eğitim videoları işaret dili destekli olarak hazırlanmıştır (MEB, 2021).

Türkiyede yapılan çalışmalara rağmen uzaktan eğitimle öğrencilerin tamamına ulaşılamamıştır. Öğrenim gören yaklaşı 18 milyon öğrencinin ancak yedi milyonu EBA platformuna erişim sağlayabilmiştir (MEB, 2020). Bu durumda ülkemizin internet ve teknolojik altyapısının da payı bulunmaktadır. MEB, UNICEF ve UNESCO verilerinde ortaya konulan durum basın ve yayın organları aracılığıyla toplum gündeminde de yer almaktadır. Bu haberlerden bazılarına aşağıda yer verilmiştir. 


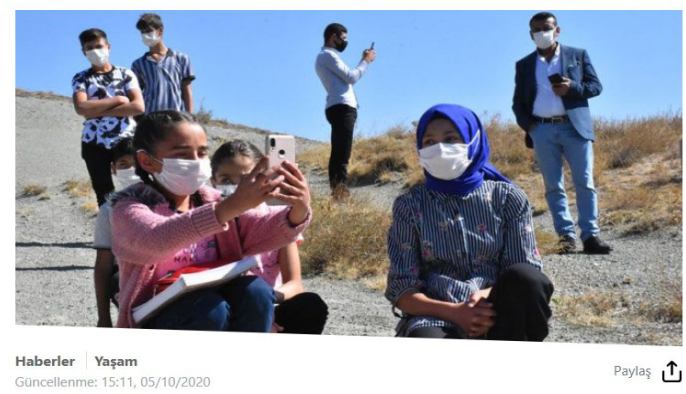

\section{Köyde uzaktan eğitime katılmak için tepeye çıkıyor!}

Sivas merkeze bağlı Zengi köyünde yașayan 40 ögrenci, derslere katılabilmek için 1 kilometre yürüyerek internetin çektiği tepeye çıkıyor.

Korkusuz Gazetesi, 15.11.2020

\section{Öğrencilerin internet çilesi}

Aydin'in Kullor Mahallesi'nde yasayan 50 ärrenci online ders görmek icin internetin çektiği 600 metre yükseklikteki kayaliklara trrmanmak zorunda kalıyor.
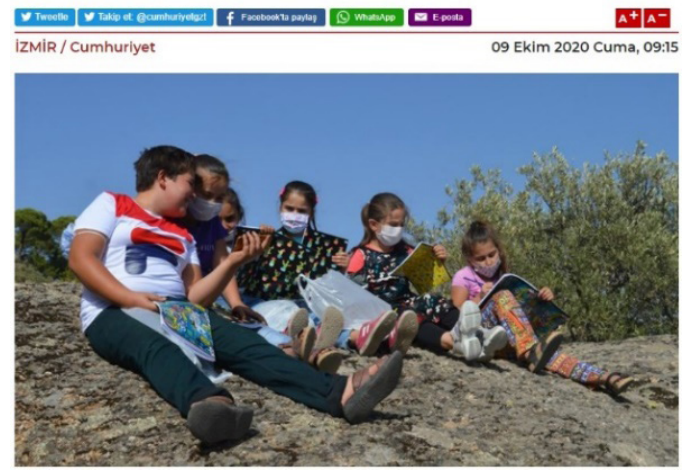

Cumhuriyet Gazetesi, 09.10.2020

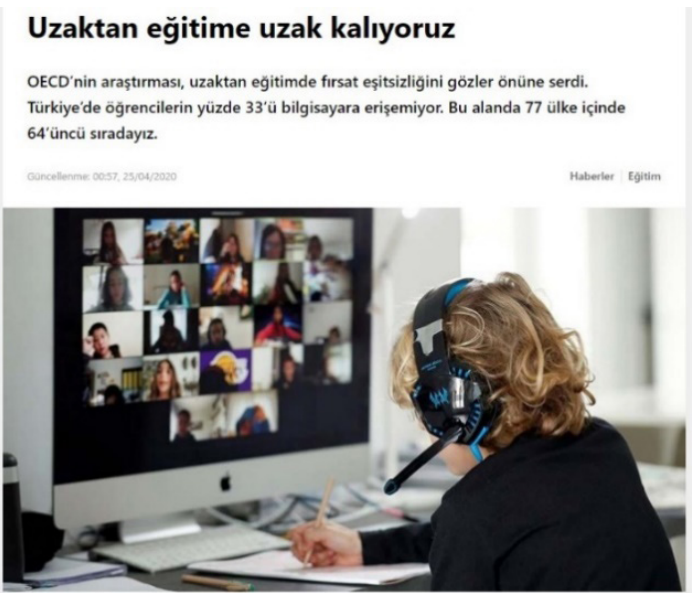

Sözcü Gazetesi, 25.042020

\section{Internete erișimin olduğu tek yer cami terası uzaktan eğitim sınıfı oldu}

\section{Gaziantep'in İslahiye ilçesine bağı Koccağız Mahallesi'nde yaşayan bir grup öğrenci, her gün uzaktan} egitime katilabilmek için mahallenin tek internet erişiminin olduğu cami terasına çikyorlar. Aralarninda ellerine aldıklan tablet ve cep telefonlan ile anlı derslere kattlım sağlyor. Öğrenciler, kiş gelmeden yaşanan internet sorununun çözüm bulmasinı istiyorlar.

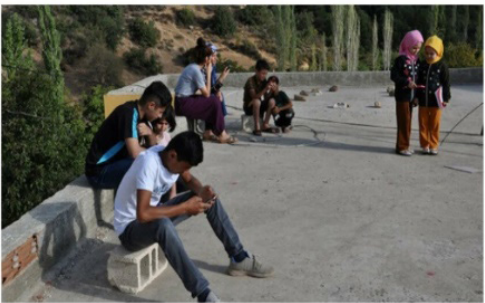

Gazete haberlerinde öğrencilerin uzaktan eğitime katılmada yaşadıkları sorunlar gündeme getirilmiştir. Bu haberlere göre öğrenciler; internet altyapısı, teknolojik araç eksikliği ve fırsat eşitsizliği gibi konularda sorunlar yaşamaktadır. Ailelerin ve çocukların, eğitime erişim sağlamak için internete erişebilecekleri yüksek yerlere çıkarak ve teknolojik araçları ortak kullanarak çözüm üretmeye çalıştıkları görülmektedir. Sosyal durumların hicivle gözler önüne serildiği karikatür yayınlarında, uzaktan eğitime erişim konusunda da örnekler verilmiştir. Bu karikatür örneklerinden bazılarına aşağıda yer verilmiştir.

Şekil 2. Uzaktan eğitime dair karikatürler
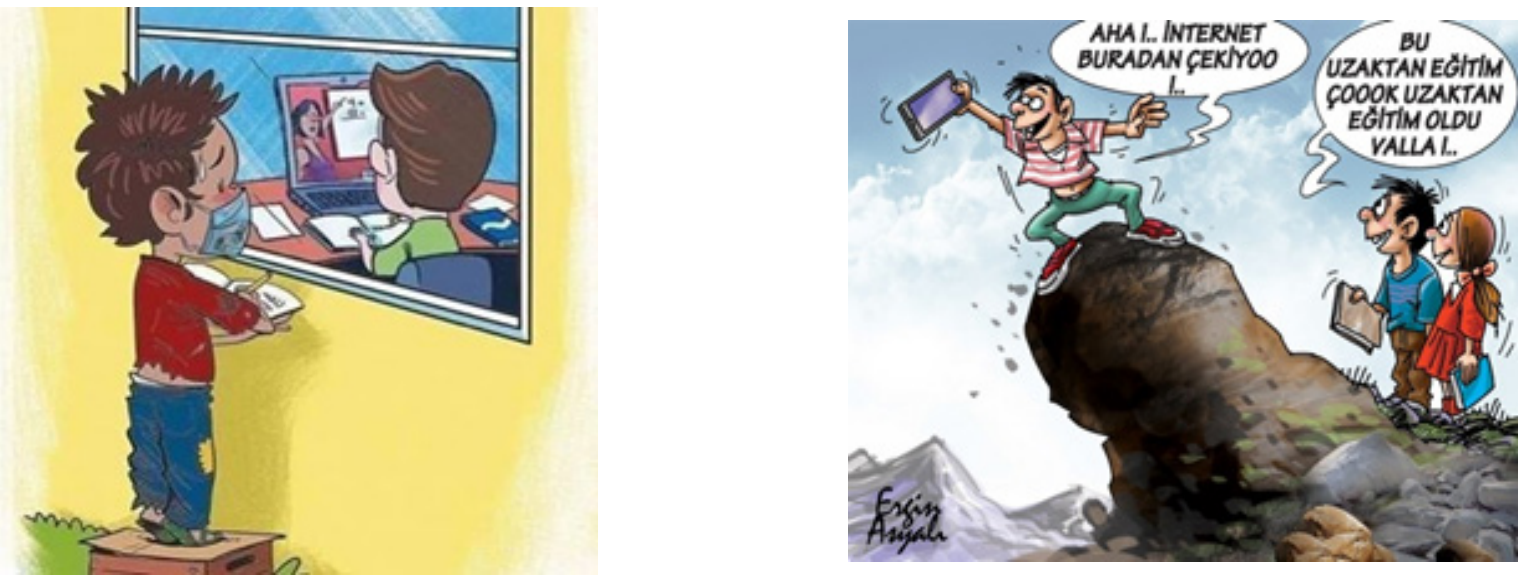
Ülkemizde eğitim alanında fırsat eşitliği önemli bir sorundur ve çocukların eğitim haklarına erişmede salgın süreci zorlayıcı bir etmen olarak ortaya çıkmıştır. Tüm dünyada olduğu gibi Türkiye’de de eğitimin aksamaması için yapılan birçok faaliyete rağmen, çeşitli nedenlerden dolayı uzaktan eğitime erişemeyen öğrenciler bulunmaktadır. Basın ve yayın organlarında yer alan haberler ve karikatürlerde de görüleceği üzere, öğrenciler ve veliler uzaktan eğitime erişime dair sorunlarına bireysel çabalarla çözüm yolları bulmaya çalışmaktadır. Öğrencilerin uzaktan eğitime erişememesinde sosyo-ekonomik, teknolojik altyapı eksikliği, fırsat eşitsizliği gibi nedenler yer almaktadır. Tüm dünyada olduğu gibi Türkiye’de de salgın sürecinde, öğrencilerin uzaktan eğitime erişimiyle ilgili sınırlılıklar bulunmaktadır. Öğrencilerin büyük çoğunluğu bu süreçte EBA'ya giriş bile yapmazken bu öğrencilerin eğitim süreçlerini nasıl sürdürdüğü, TRT EBA TV'ye erişim durumlarını, TRT EBA TV içeriklerin sürece olan desteği ve izlenme oranı, ailelerin öğrencilerdeki öğrenmesine katkı sağlama durumları bilinmemektedir (TEDMEM, 2020, s. xviii).

Uzaktan eğitimin niteliğinin tartışıldığı bugünlerde, eğitim paydaşlarının uzaktan eğitim ile ilgili görüşlerinin alınması, geleceğe yönelik yapılacak eğitim faaliyetlerine ışık tutması açısından önem kazanmaktadır. Salgın sürecindeki uzaktan eğitime yönelik yapılan araştırmalar incelendiğinde; öğrencilerin kardeşleriyle derslerinin aynı zamana denk gelmesi, odaklanmada zorluk yaşamaları, katılımlarının az olması, TRT EBA TV'nin etkisiz olması, altyapı sorunlarının olması, fırsat eşitliğinin sağlanamaması, ailelerin sosyo-ekonomik imkânlarının sınırlı olması, bireysel farklılıkların dikkate alınmaması ve velilerin ilgisiz olması gibi durumların en sık ifade edilen sorunlar olduğu görülmektedir (Başaran vd, 2020, s. 368; Bozkurt, 2020, s. 125; Doğan ve Koçak, 2020, s. 122; Fidan, 2020, s. 32; Özer ve Suna, 2020, s. 363; Türk Tabipler Birliği, 2020, s. 564; Yıldız, 2020, s. 852).

Nitelikli bir uzaktan eğitim için yaşanan sorunların irdelenmesi gerekmektedir. Bu nedenle uzaktan eğitim konusu üzerine yapılacak çalışmalar önem arz etmektedir. Hem Türkiye’de uzaktan eğitimin niteliğinin araştırılmasının hem de uzaktan eğitime ulaşamayan ilkokul öğrencilerinin ve ailelerinin yaşam öykülerine kulak verilmesinin, duygu ve düşüncelerinin ortaya konulmasının önemli olduğu düşünülmektedir. Araştırma ile sınıf öğretmenlerinin ve velilerinin gözünden öğrencilerin uzaktan eğitim sürecine katılma/katıl(a)mama durumlarına ve süreç boyunca yaşananlara yönelik görüşlerinin değerlendirilmesi amaçlanmıştır. Bu çerçevede araştırmanın soruları aşağıdaki gibidir:

1. Öğretmen ve veli görüşlerine göre öğrencilerin uzaktan eğitime katıl(a)mama nedenleri nelerdir?

2. Öğretmenlerin uzaktan eğitime katıl(a)mayan öğrenciler için geliştirilen çözüm yollarına ilişkin bakış açıları nelerdir?

3. Öğretmen ve velilerin uzaktan eğitime katılım ile ilgili duygu, düşünce ve anıları nelerdir?

\section{Yöntem}

Covid-19 salgını sebebiyle ülkemizde yaygın biçimde uygulanmaya başlanan uzaktan eğitimin niteliğinin araştırılması ve uzaktan eğitimle ilgili ilkokul öğrencilerinin ve ailelerinin hikâyelerinin ortaya konmasının amaçlandığı bu araştırmada nitel araştırma yaklaşımı benimsenmiştir. Gerçekleştirilen bu araştırma, uzaktan eğitim faaliyetlerine ilişkin öğretmenlerin ve ailelerinin görüşleri ve önerilerinin tespit edilmesi amacıyla iç içe geçmiş tek durum deseni kullanılarak hazırlanmış bir durum çalışmasıdır. İç içe geçmiş tek durum deseni tek bir durum başlığı altında birden fazla alt birim veya tabaka olan, birden fazla analiz biriminin söz konusu olduğu durum çalışması desenidir (Yıldırım ve Şimşek, 2018, s. 301). Bu araştırmada uzaktan eğitim faaliyetlerinin değerlendirilmesi durumu için paydaşların her biri farklı analiz birimi olarak düşünülmüştür.

\section{Çalışma Grubu}

Çalışma grubunu 2020-2021 eğitim-öğretim yllında ilkokullarda görev yapan 36 sınıf öğretmeni ile ilkokul kademesinde öğrenim gören çocuğu bulunan 18 veli oluşturmaktadır. Araştırmanın katılımcıları gönüllülük esasına göre belirlenmiştir. Yıldırım ve Şimşek (2018, s. 124) nitel araştırmalarda birden fazla örnekleme yönteminin bir arada kullanılabileceğini, araştırmanın her aşamasında örneklem seçme ve belirlemenin yeniden değerlendirilerek yeni örnekleme yöntemlerinin sürece dahil edilebileceğini belirtmektedir. Bu araştırmada da katılımcıların belirlenmesinde kolay ulaşılabilir durum örneklemesi ile ölçüt örnekleme birlikte kullanılmıştır. Kolay ulaşılabilir örnekleme yöntemi tercih edilmesinin nedeni, araştırmacıların görev yaptıkları okullarda ve sosyal çevrelerinde bulunan katılımcılara ulaşmasının kolay olmasıdır. Araştırma ilkokul kademesinde öğrenim gören öğrencilerle sınırlandırıldığı için ilkokullarda görev yapan ve uzaktan eğitim faaliyetlerinde bulunan sınıf öğretmenleri ile en az bir çocuğu ilkokulda öğrenim gören velilerin seçilmesi ise ölçüt olarak belirlenmiştir.

Çalışma grubunda yer alan sınıf öğretmenlerinin, mesleki deneyimleri 0-5 yıl (sekiz kişi), 6-10 yıl (iki kişi), 11-15 
yıl (sekiz kişi), 16-20 yıl (beş kişi), 20+ yıl (13 kişi); öğrenim durumları ön lisans bir kişi, lisans 30 kişi, yüksek lisans beş kişi; çalıştıkları sınıf kademesi birinci sınıf dört, ikinci sınıf sekiz, üçüncü sınıf dokuz, dördüncü sınıf 15; sınıf mevcutları 0-20 kişi (5), 21-30 kişi (16), 31-40 kişi (12), 40+ kişi (3) olarak dağılım göstermektedir.

Çalışma grubunda yer alan velilerin, öğrenim durumları ilkokul (sekiz), ortaokul (beş) ve lise (beş) şeklindedir. Velilerden üçü tam zamanlı bir işte çalışırken, 15’i herhangi bir işte çalışmamaktadır. Dört velinin okul çağında bir çocuğu, 10 velinin iki çocuğu bulunurken, iki velinin üç çocuğu, iki velinin ise dört çocuğu bulunmaktadır.

\section{Veri Toplama Araçları}

Araştırma verilerinin toplanmasında çevrimiçi anket formları ve yarı yapılandırılmış görüşme formları kullanılmıştır. Çevrimiçi anket ve yarı yapılandırılmış görüşme formları, araştırmacılar tarafından dört sınıf öğretmeninin görüşlerinden ve alan yazından faydalanılarak oluşturulmuştur. Nitel araştırma yöntemleri konusunda bir uzmanın görüşleri doğrultusunda formlarda gerekli düzenlemeler yapılmış ve iki gönüllü sınıf öğretmeniyle pilot uygulama gerçekleştirilmiştir. Uygulama sonrasında formlara son hali verilmiştir. Çevrimiçi anket formu iki kısımdan oluşmaktadır. İlk kısımda katılımcıların demografik bilgileri, ikinci kısımda ise uzaktan eğitime ulaşamama durumları ve bu durumlar karşısında katılımcıların yaşadıkları duygu ve düşünceler sorgulanmıştır. Çevrimiçi olarak 36 öğretmen ve 18 veliye ulaşılmıştır. Katılımcılar arasından, kolay ulaşılabilir olması göz önünde bulundurularak üç veli ve üç öğretmen ile de yüz yüze görüşmeler gerçekleştirilmiştir. Kolay ulaşılabilir durum örneklemesinde araştırmacı, erişimi kolay ve yakın olan durumu seçmektedir (Yıldırım ve Şimşek, 2018, s. 123). Bu araştırmada da araştırmacıların yüz yüze görüşmelerine imkân sağlayacak yakınlıkta ve erişilmesi açısından kolay olması göz önünde bulundurularak kendi çalıştıkları okullardan seçilen öğretmen ve velilerle yüz yüze görüşmeler sağlanmıştır. Görüşme, iki kişi arasında sözlü olarak sürdürülen, araştırmada cevabı aranılan sorular çerçevesinde ilgili kişilerin bilgileri, tecrübeleri, duygu ve düşünceleriyle alakalı olarak doğrudan alıntılar yapılmasına imkân sağlayan bir iletişim sürecidir (Büyüköztürk vd., 2015, s. 150). Görüşme esnasında alınan yanıtlara dair notlar tutulmuş, aynı zamanda yapılan görüşmeler ses kayıt cihazıyla kayıt altına alınmıştır. Araştırmanın verileri toplanmaya başlanmadan önce Marmara Üniversitesinden etik kurul onayı alınmıştır. Bunun yanı sıra verilerin toplanma aşamasında anket ve görüşme yapılan katılımcılardan etik ilkeler gözetilerek, araştırmaya dair bilgi verilip yazılı ve sözlü beyana dayalı gerekli izinler alınmıştır.

\section{Verilerin Analizi}

Çevrimiçi anket formlarından alınan verilerle bu verileri derinleştirmek amacıyla veli ve öğretmenlerle gerçekleştirilen görüşmelere ilişkin ses kayıtları dinlenilerek yazıya aktarılmıştır. Ardından görüşmeler esnasında tutulan notlar ile bu veriler birleștirilerek ham veriler elde edilmiştir. Elde edilen veriler içerik analizi kullanılarak analiz edilmiştir. İçerik analizinde esas işlem, benzer verileri belirli kavramlar ve temalar altında bir araya getirerek yorumlamaktır (Yıldırım ve Şimşek, 2018, s. 242). Bu doğrultuda veli ve öğretmenlerin görüşleri kavramsallaştırılarak kodlar oluşturulmuş, ortaya çıkan kodlar benzerlik ve farklılıkları dikkate alınarak tema başlıkları altında toplanmıştır. Toplanan kod ve oluşturulan temalar tablolar halinde sunularak bulgular verilmiş ve yorumlanmıştır. Araştırmada öğretmen ve velilerin görüşlerini yansıtmak amacıyla doğrudan alıntılara yer verilmiştir. Öğretmen ve velilerin alıntılarına yer verilirken öğretmenler için (Ö1, Ö2, Ö3, ...), veliler için (V1, V2, V3, ..) yüz yüze görüşme yapılan öğretmenler için (ÖG1, ÖG2, ÖG3), yüz yüze görüşme yapılan veliler için (VG1, VG2, VG3) kısaltmaları kullanılmıştır.

Araştırmanın güvenirliğinin sağlanması için çevrimiçi anket formları ve görüşmeler sonucunda elde edilen veriler, araştırmacılar haricinde bir uzman tarafından da kodlanarak tema ve kategorilere ayrılmıştır. Araştırmacıların kodlamaları karşılaştırılmış ve Miles ve Huberman (1994) tarafından ortaya konan Görüş Birliği / (Görüş Birliği + Görüş Ayrılığı) x 100 formülüne göre güvenirlik değeri 0,88 olarak hesaplanmıştır. Formüle göre güvenirlik değeri 0,70 ve üstü olması kabul edilmektedir. Fikir ayrılığına düşülen kodlamalar tekrar incelenmiş, tartışılmış ve fikir birliğine varılarak temaların, alt temaların ve kodlamaların son hali verilmiştir. Fikir ayrılığına düşülen kodlamalar yeniden gözden geçirilerek, fikir birliğine varılmış, kodlamaların son hali verilmiştir.

\section{Bulgular}

\section{1- Öğretmen ve veli görüşlerine göre öğrencilerin uzaktan eğitime katıl(a)mama nedenleri nelerdir?}

Araştırmanın "Öğretmen ve veli görüşlerine göre öğrencilerin uzaktan eğitime katıl(a)mama nedenleri nelerdir?" şeklinde ifade edilen birinci alt problemine ilişkin bulgular öğretmen ve veli görüşleri olarak analiz edilmiştir. Elde edilen bulgular tablolar halinde verilmiştir. Öğrencilerin uzaktan eğitime katıl(a)mama nedenlerine ilişkin 
öğretmenlere “Size göre uzaktan eğitime katıl(a)mayan öğrencilerinizin katıl(a)mama nedenleri nelerdir?” sorusu sorularak Tablo 1'deki bulgular elde edilmiştir.

Tablo 1. Öğrencilerin Uzaktan Eğitime Katıl(a)mama Nedenlerine İlişkin Öğretmen Görüşleri (n=36)

\begin{tabular}{clc} 
Tema Ana Başlığı & Alt başlık & (f) \\
Sosyo-ekonomik nedenler & Maddi sebepler nedeniyle internet, teknolojik altyapı ve donanım eksikliği & 26 \\
$\mathbf{2 7}$ & Kardeş sayısı & 1 \\
\cline { 2 - 3 } Velilerle ilgili nedenler & Ailenin ilgi göstermemesi, destek ve önem vermemesi & 11 \\
$\mathbf{1 4}$ & Ailenin yeterli bilgi/eğitime sahip olmaması & 3 \\
\hline Öğrencilerle ilgili nedenler & Öğrenci isteksizliği & 1 \\
\cline { 2 - 3 } Öğretmenlerle ilgili nedenler & Özel/yabancı uyruklu çocuklara çeşitli nedenlerle ulaşamama & 1 \\
\hline 1 & &
\end{tabular}

Tablo 1'deöğrencilerinuzaktaneğitimekatıl(a)mamanedenlerineilişkinöğretmengörüşleriyeralmaktadır.Öğretmenlerin önemlibirkısmının, sınıflarında tam katılımın olmadığını, öğrencilerin canlı derslere girmede sorunlaryaşadıklarınıbelirttiği görülmektedir. Buna karşın üç öğretmen derslerine tam katılımın sağlandığını söylemiştir. Öğrencilerin uzaktan eğitime katıl(a)mamasına dair en sık söylenen öğretmen görüşleri ise "Sosyo-ekonomik nedenler" ve "Velilerle ilgili nedenler" tema ana başlıkları altında toplanmıştır. Bu ana başlıklar altında "Maddi sebepler nedeniyle internet, teknolojik altyapı ve donanım eksikliği”" ve "Ailenin ilgi göstermemesi, destek ve önem vermemesi” öğretmenlerce sıklıkla ifade edilmiştir. Öğrencilerin önemli bir kısmının canlı derslere katılabilecek teknolojik araç-gerece sahip olmadıkları anlaşılmaktadır. Bununla birlikte interneti olmayan ya da internete sahip olup canlı ders platformlarına bağlantıda sorun yaşayan öğrencilerin de varlığından söz edilebilir. Donanım ve alt yapı eksikliğinin yanında uzaktan eğitim sürecine ilişkin ailelerin yeterli bilgiye ve eğitime sahip olmamaları da öğrenci katılımını etkilemektedir. Öğretmen görüşlerine göre maddi desteklerin yanı sıra öğrencilerin derslere katılmalarında manevi destek de önem taşımaktadır. Ailelerin canlı derslere gereken ilgiyi göstermemeleri, önem vermemeleri ya da canlı derse girmede öğrenciye destek olmamaları da öğrenci motivasyonunun düşmesine neden olmaktadır. Bu doğrultuda bazı öğrenciler de canlı derslere gereken önemi göstermemekte, canlı derslere girmede isteksiz olmaktadırlar. Tüm bu nedenlerin yanında yabancı uyruklu ya da özel gereksinime sahip bazı öğrenciler de bu süreçte yeterli desteği görememektedir. Elde edilen veriler, canlı derslere katılmada her öğrencinin eşit şartlara sahip olmadığını göstermektedir. Uzaktan eğitim sürecine her öğrencinin eşit şartlarda katılamaması ve eğitim paydaşlarından aynı desteği görememesi firsat eşitliğinin önündeki en büyük engel olarak görülmektedir. Uzaktan eğitim sürecine katılamamada en sık dile getirilen başlıklara ait örnek öğretmen görüşleri şu şekildedir:

Ö16:

Gerekli alt yapının olmayışı en büyük etken.Bunun yanında bu teknolojiyi kullanacak bilgiye sahip olmamak.
Ekonomik gelirin düşük olması.Çocuk sayısının fazla ve/fakat araç gerecin az olması. Internet alt yapısı ve
kullanılan eğitim platformlarının yükü kaldıramayışı.

Ö11:

Öğrenci olan kardeş sayısı,evde internet bağlantısı olmaması,cihaz sayısının yetersizliği.

Öğretmen görüşlerinde görüldüğü gibi Ö16 ve Ö11, açıklamalarında konuyla ilgili pek çok soruna temas etmekte ve benzer şeylerin altını çizmektedir. Ö16’ya göre sorunun oluşmasına en büyük etken "gerekli alt yapının olmayışı"dır. Nitekim Ö11 de "evde internet bağlantısı olmaması" sorununu ifade ederken aynı altyapı sorununa işaret etmektedir. Yine iki öğretmenin birlikte söz ettikleri önemli bir sorun da çocuk/öğrenci sayısının fazla olmasından kaynaklanan cihaz (bilgisayar, tablet ve televizyon gibi) sayısının yetersizliğidir. Ekonomik gelirin düşük olması da hem internet bağlantısının olmaması hem de cihaz yetersizliğinin gerekçesi gibi görülmektedir. Bundan başka Ö16, bir başka noktaya da dikkat çekmektedir ki bu uzaktan eğitim için yaşamsal derecede önemlidir; teknoloji okuryazarlığı. Çünkü sadece paranızın olması ve internet hizmeti ile cihazları satın almanız yeterli değildir. İnternet ile cihazları çalıştırmanızı sağlayacak teknoloji kullanma donanımına da sahip olmanız önemlidir. Tüm bunlardan başka Ö16 artan uzaktan eğitim talebi nedeniyle internet altyapısındaki yetersizlik sorunlarını da gündeme getirmektedir. 
Araştırma bulgularının çevrimiçi platform üzerinden anket ile elde edilmesinden iki ay sonra üçöğretmenle yüzyüze görüşmeler gerçekleştirilmiştir. Bu görüşmelerde uzaktan eğitime katılamayan öğrencilerin, geçen bu sürede derslere katılamama nedenlerinde değişiklik oluşmasına dair öğretmen görüşleri alınmış ve öğretmenlerden “öğrencilerin uzaktan eğitime katılamama nedenlerinde değişiklikler oldu mu?” sorusuna yanıt vermeleri beklenmiştir. Bu konu hakkında ÖG1 öğrencilerin sürecin başında uzaktan eğitime katılamama nedenlerini "tabletlerin, bilgisayarların, cep telefonlarının ve internetin eksikliği" olarak dile getirirken; daha sonradan ailelerin bu eksikliklerini tamamlamasına rağmen derslere katılamama sorununun halen sürdüğünü, bunun nedeni olarak da "ailesinde Covid-19 vakası olan öğrencilerde psikolojik sorunların gözlenebildiğini” ifade etmiştir. Benzer şekilde ÖG3 de öğrencilerinin teknolojik ihtiyaçlarının giderilmiş olsa da hala bazı öğrencilerinin uzaktan eğitime katılmadığını belirtmiştir. Bu duruma gerekçe olarak ise öğrenci isteksizliği ve yeterli veli desteğinin olmayışını "Veli desteği olmayınca ne yazık ki öğrenci sabah kalkmıyor derslere yetişemiyor. Ev çalışmalarını yapmıyor. Bu nedenle de geri kalıyorlar" şeklinde ifade etmiştir. ÖG2 ise salgın sebebiyle işten çıkarılan çok sayıda velilerinin olduğunu, maddi imkânların sınırlı oluşuna "Günü geçirmeye parasl, yiyecek ekmeği yokken interneti bulamaz, tableti düşünemez ki” ifadesiyle dikkat çekerek bu nedenlerden dolayı da öğrencilerinin gerekli teknolojik aletleri hala temin edemediklerini ifade etmiştir. Aşağıda ise öğrencilerin uzaktan eğitime katıl(a)mama nedenlerine ilişkin velilere "Uzaktan eğitim sürecinde çocuğunuz derslere düzenli olarak katılabiliyor mu? Gerekçeleriyle açıklayınız.” sorusu sorularak Tablo 2'deki bulgular elde edilmiştir.

Tablo 2. Öğrencilerin Uzaktan Eğitime Katıl(a)mama Nedenlerine İlişkin Veli Görüşleri (n=18)

\begin{tabular}{clc} 
Tema Ana Başlı̆̆ı & Alt başlık & (f) \\
& Maddi sebepler & 2 \\
Hayır katılamıyor & İnternet ve teknolojik altyapı eksikliği & 2 \\
7 & Kardeş sayısı & 2 \\
& Teknolojik araç ve donanım eksikliği & 1 \\
\hline
\end{tabular}

Tablo 2'de öğrencilerin uzaktan eğitime katıl(a)mama nedenlerine ilişkin veli görüşleri yer almaktadır. Ortaya çıkan verilere göre öğrencilerin yarısına yakın bir kısmı uzaktan eğitime katıl(a)mamaktadır. Veliler bu durumun "Maddi sebepler nedeniyle internet, teknolojik altyapı ve donanım eksikliği" gibi nedenlerden kaynaklandığını ifade etmişlerdir. Ayrıca bazı velilerin "Kardeş sayısı" ifadesiyle evdeki çocukların hepsine yetecek teknolojik aracın olmamasından dolayı çocukların uzaktan eğitime katılamadıklarını belirtmişlerdir. 11 veli ise kısmen veya tamamen uzaktan eğitime katılabildiğini ifade etmiştir. Velilerin çocuklarının uzaktan eğitime katılamama nedenlerine yönelik belirtmiş oldukları görüşleriyle, Tablo 1'de yer alan öğretmen görüşlerinin benzerlik gösterdiği görülmektedir. Buna ilişkin olarak örnek veli görüşleri aşağıda verilmiştir:

V1:

Katılabiliyor fakat bazı durumlarda derslere açılmıyor veya sisteme giriş yapamıyor

V8:

Katılıyor ama benim telefonundan giroyorlar onun dersi bitince abisi giriyor derse

V9:

$$
\text { Teknoloji yetersizliği nedeniyle zaman zaman karşılamıyorlar }
$$

V14:

$$
\text { Yok derslere katılamıyor çünkü evde internet yok eve kendi çabamizla bi şeyler gösteriyoruz }
$$

V16:

$$
3 \text { kardeşler birbirinin saatleri çakıştıgı için fırsat buldukça gitmeye çalışıyorlar }
$$


Yukarıda da görüldüğü gibi V14 internet olmamasından dolayı öğrencinin derse katılamadığını belirtmiştir. Derse katılamayan bazı öğrencilerin velileri V14 örneğinde olduğu gibi çocuklarının oluşan eğitim eksiklerini kendi çabaları ile gidermeye çalışmaktadırlar. Uzaktan eğitime katılamamak ile ilgili ifade edilen sebeplerden bir diğeri de evdeki her çocuğa yeterince teknolojik araç bulunmamasıdır. V8 ve V16 bu konuya değinmişlerdir. Bununla birlikte V9 da teknolojik alet eksikliğinden dolayı öğrencinin zaman zaman derslere katılamadığını ifade etmiştir. Teknolojik alet eksikliği nedeniyle derslere katılamayan öğrencilerin yanı sıra katılan bazı öğrenciler de V1'in belirttiği gibi teknolojik/sistemsel sorunlardan kaynaklı derslere uygun şekilde giriş sağlayamamaktadır.

Veliler ile gerçekleştirilen görüşmeler nihayetinde velilere "Çocuklarınızın uzaktan eğitime katılamama nedenlerinde bir değişiklik oldu mu?” sorusu yöneltilerek elde edilen bulgular aşağıda ifade edilmiştir. Konuya ilişkin olarak VG1 uzaktan eğitim sürecinin başlangıcında internet bağlantıları olmadığı için çocuklarının derslere katılmakta güçlük yaşadığını ifade etmiştir. Soruna "Komşudan da bağlanarak, merdiven boyunda 1-2 ay boyunca ödev yaparak" çözüm getirmeye çalıştıklarını ifade etmiştir. Benzer şekilde VG2 de uzaktan eğitim sürecinin başlangıcında katılımda sorun yaşadıklarını belirtmiştir. Sorunu çözmek adına harcadıkları çabaları "ilk başta evimde internet yoktu ama ben çocuğumun katılması için sını öğretmeni de bilir, okuldaki EBA destek noktasından yararlandım. Her gün götürüyordum girmeye çalışıordu çocuk bazen bağlanamıyorduk, görüntümüz olmasa da sesimiz gidiyordu kulaklıkla. Yani bir şekilde çocuklarımı sokmaya çalıştım" ifadeleriyle dile getirmiştir. Son durumda ise telefondan derslere bağlanmaya çalıştıklarını ifade etmiştir.

\section{2- Öğretmenlerin uzaktan eğitime katıl(a)mayan öğrenciler için geliştirilen çözüm yollarına ilişkin bakış açıları nelerdir?}

Araştırmanın "Öğretmenlerin ve velilerin uzaktan eğitime katıl(a)mayan öğrenciler için geliştirilen çözüm yollarına ilişkin bakış açıları nelerdir?” şeklinde ifade edilen ikinci alt problemine ilişkin bulgular öğretmen ve veli görüşleri olarak analiz edilmiştir. Elde edilen bulgular tablolar halinde verilmiştir. Uzaktan eğitime katılamayan öğrenciler için öğretmenlere "Size göre uzaktan eğitime katılamayan öğrenciler için neler yapılabilir" sorusu sorularak Tablo 3'teki bulgular elde edilmiştir.

Tablo 3. Uzaktan Eğitime Katılamayan Öğrenciler İçin Neler Yapılabileceğine Yönelik Öğretmen Görüşleri (n=36)

\begin{tabular}{|c|c|c|}
\hline Tema & Kodlar & (f) \\
\hline \multirow{7}{*}{$\begin{array}{l}\text { Devletten Beklenilenler } \\
29\end{array}$} & İnternet, teknolojik donanım ve altyapı desteği sağlanması & 23 \\
\hline & Yüz yüze eğitimin devam ettirilmesi & 2 \\
\hline & Okullardaki EBA noktalarında görevliler bulundurulması & 1 \\
\hline & Yaptırım uygulanması & \\
\hline & Canlı derslere devam zorunluluğu & 2 \\
\hline & EBA TV izlenmesini zorunlu kılınması & 1 \\
\hline & Süreç sonunda telafi eğitimi yapılması & 1 \\
\hline \multirow{2}{*}{$\begin{array}{c}\text { Aileden Beklenilenler } \\
\mathbf{8} \\
\end{array}$} & Öğrencinin derslerine karşı ilgili olmaları & 5 \\
\hline & Farkındalık sağlamaları ve bilinçlenmeleri & 3 \\
\hline \multirow{2}{*}{$\begin{array}{l}\text { Öğretmenden Beklenilenler } \\
4\end{array}$} & Ödev vermeleri & 3 \\
\hline & İletişim halinde olmaları & 1 \\
\hline $\begin{array}{c}\text { Toplumdan Beklenilenler } \\
2\end{array}$ & Sosyal sorumluluk projelerinin üretilmesi & 2 \\
\hline
\end{tabular}

Tablo 3’te uzaktan eğitime katılamayan öğrenciler için neler yapılabileceğine yönelik öğretmen görüşleri yer almaktadır. Ortaya çıkan verilere göre öğrenciler için yapılabilecek uygulamalara dair en sık ifade edilen öğretmen görüşleri sırasıyla "Devletten, Aileden, Öğretmenden ve Toplumdan Beklenilenler" temaları altında toplanmıştır. Bu temalar altında da uzaktan eğitime katılamayan öğrenciler için devletten "İnternet, teknolojik donanım ve altyapı desteği sağlaması", ailelerden "Öğrencinin derslerine karşı ilgili olmaları", öğretmenlerden "Ödev vermeleri" ve toplumdan "Sosyal sorumluluk projelerinin üretilmesi” öğretmenler tarafından en sık telaffuz edilen görüşlerdir. Bu bağlamda öğretmenlerin ailelerin yeterince destek ve ilgi göstermediklerini düşünerek, ailelerden derslere karşı ilgili olmalarını, farkındalık sağlamalarını ve bilinçlenmelerini bekledikleri gözlenmektedir. Ayrıca öğretmenler, uzaktan eğitime erişemeyen öğrencilere ödev verilebileceğini ve aile ile iletişimde kalmanın önemini ifade etmişlerdir. Öğretmenler devlet kanalıyla en çok öğrencilere teknolojik araç gereç ve internet temin edilmesi ve bu konudaki sorunlarının çözülmesini beklerken bunun yanı sıra internet üzerinden yapılan ders yerine yüz yüze eğitime devam edilmesinden 
yana olan öğretmenler de bulunmaktadır. Ayrıca bazı öğretmenler, uzaktan eğitime erişim imkânı bulunan öğrenciler için de devam zorunluluğu olması için devlet kanalıyla yaptırım uygulanması gerektiğini düşünmektedir. Bu ifadelere ilişkin olarak Ö1 ve Ö16 görüşlerini şu şekilde ifade etmiştir:

Ö1:

Öncelikle internet konusunda en azından sadece eğitim için kullanabilecekleri bir miktar sağlanmalı. Sonrasında tablet desteği kesinlikle lazım

Ö16:

Kendi adıma bu çocuklarla yüz yüze eğitimden başka çözüm düşünemiyorum.Çünkü ailelerin de eğitimin gereğine ve önemine gerçekten inanması gerekir.Ki çözüm önerilerini uygulasınlar.

Yukarıda da görüldügü gibi Ö1 devlet desteği ile sadece eğitim amacıyla kullanılabilecek internet paketi önerisi getirmekte ve teknolojik alet yetersizliği yaşayan öğrencilere tablet desteği sağlanmasını beklemektedir. Ö16 ise aile desteği konusunda yaşadığı yetersizliklere çözüm olarak, yüz yüze eğitime dönülmesinden başka çare görememektedir. Öğretmenlerin uzaktan eğitime katıl(a)mayan öğrenciler için geliştirilen çözüm yollarına ilişkin bakış açılarının ortaya konulmasının yanı sıra öğretmenlerin harcamış oldukları bireysel çabaların da tespit edilmesi amacıyla öğretmenlere “Uzaktan eğitime katılamayan öğrenciler için telafi edici çalışmalarınız var mıdır? Varsa nelerdir?” sorusu yöneltilmiştir. Öğretmenlerin verdikleri yanıtların analiz sonuçlarına aşağıda Tablo 4’te yer verilmiştir:

Tablo 4. Uzaktan Eğitime Katılamayan Öğrenciler İçin Öğretmenlerin Telafi Edici Çalışmaları (n=36)

\begin{tabular}{|c|c|c|}
\hline Tema & Kodlar & (f) \\
\hline \multirow{10}{*}{$\begin{array}{c}\text { Telafi Edici Çalışmalarım Var } \\
38\end{array}$} & Ödev vermek & 22 \\
\hline & Sosyal iletişim uygulamaları üzerinden ödevlendirme & 18 \\
\hline & Yardımcı kaynak kitaptan ödevlendirmek & 2 \\
\hline & Kitap okumaya teşvik etmek & 1 \\
\hline & Fotokopi ile ödevlendirme & 1 \\
\hline & Öğrencilere video göndermek & 8 \\
\hline & Telefonla ders anlatmak & 3 \\
\hline & EBA platformuna yönlendirmek & 2 \\
\hline & TRT EBA TV’ye yönlendirmek & 2 \\
\hline & Ders saatleri dışında ek canlı ders & 1 \\
\hline \multirow{3}{*}{$\begin{array}{c}\text { Telafi Edici Çalışmalarım Yok } \\
9\end{array}$} & Veli ilgisizliği & 2 \\
\hline & Öğrencinin derse ilgisizliği & 1 \\
\hline & Öğrencinin internet erişimininin olmaması & 1 \\
\hline Açılklama Yapılmamış & & 5 \\
\hline
\end{tabular}

${ }^{\star B}$ Beş ögretmen arasında yer alan üç öğretmenin, uzaktan eğitime katılamayan öğrencisi olmadığı için telafi edici çalışmaları da bulunmamaktadir.

Tablo 4'te uzaktan eğitime katılamayan öğrenciler için telafi edici çalışmalara yönelik öğretmenler görüşleri yer almaktadır. Ortaya çıkan verilere göre öğretmenlerin oldukça büyük bölümü öğrenciler için telafi edici çalışmalar yürüttüğü görülmektedir. Bu anlamda öğretmenlerin uzaktan eğitim nedeniyle oluşan olumsuzlukları gidermek için çabaladıkları anlaşılmaktadır. Yine öğretmenlerce uzaktan eğitime katılamayan öğrenciler için telafi edici çalışmalara dair en sık ifade edilen görüssler sırasıyla "Ödev vermek", "Öğrencilere video göndermek" ve "Telefonla ders anlatmak” şeklinde sıralanmaktadır. Telafi edici çalışmalara yönelik olarak Ö9, Ö23 ve Ö35 görüşlerini şu şekilde ifade etmiştir: 
Ö9:

Sınıf düzeyi 2.sınof olduğu için okuma yapmaları yönünde teşvik ediyorum. Alıştırmalardan oluşan çalışmalarla ödevlendiriyorum. Velimi, öğrenciyi çalıştırmaları konısında yönlendiriyorum.

Ö23:

\section{Destekleyici video ve dökümanlar gönderiyorum}

Ö35:

\section{Internet olmayınca uzaktan telafi de olmuyor}

Yukarıda görüldüğ̈̈ gibi Ö9 ve Ö35, bazı öğrencilerinin internet imkânı olmadığından, uzaktan eğitime katılamayan öğrencileri bulunduğunu belirtmişlerdir. Ancak Ö9 velileriyle iletişim halinde olduğundan öğrencilerine ödevlendirme ve okumaya teşvik konularında destek olabilirken, Ö35 uzaktan eğitime katılamayan öğrencileri için telafi edici çalışmaları, ailelerle iletişim kuramadığı ve gerekli desteği göremediği için sağlayamadığını ifade etmektedir. Ö23 ise öğrencilerine internet ortamından ulaşabilmekte ve onlara video ve dokümanlar gönderdiğini belirterek destek olmaktadır. Öğretmen görüşleri incelendiğinde, uzaktan eğitim koşullarına uyumlu olarak ödevlerin de sosyal iletişim uygulamaları üzerinden yollandığı görülmektedir. Yeni oluşan koşullar yeni çözüm yollarını da beraberinde getirmektedir. Bunlardan başka katılımcı öğretmenlerin yine teknoloji odaklı bir çözüm olarak öğrencilere tavsiye ettikleri videoları, EBA platformunu ya da EBA televizyonunu kullanarak/izleyerek anlamaya çalışmalarını salık verdikleri anlaşılmaktadır. Uzaktan eğitimin yetmediği yerde yine teknolojik çözümler gündeme gelmektedir. Yine bazı fedakâr öğretmenlerin telefonla ders anlatmak ya da ders saatleri dışında ek canlı ders yaparak oluşan boşlukları gidermeye çabaladıkları da görülmektedir.

\section{3- Öğretmen ve velilerin uzaktan eğitime katılım ile ilgili duygu, düşünce ve anıları nelerdir?}

Araştırmanın “Öğretmen ve velilerin uzaktan eğitime katılım ile ilgili duygu, düşünce ve anıları nelerdir?” şeklinde ifade edilen üçüncü alt problemine ilişkin bulgular öğretmen ve veli görüşleri olarak analiz edilmiştir. Elde edilen bulgular tablolar halinde verilmiştir. Öğretmen ve velilerin şahit oldukları öğrencilerin uzaktan eğitime katıl(a)mama durumları ile ilgili duygu, düşünce ve anılarına dair öğretmenlere "Canlı derslerinize katıl(a)mayan öğrencileriniz için hissettiğiniz duygu ve düşünceleri detaylarıyla açıklayınız?” sorusu sorularak Tablo 5 ’teki bulgular elde edilmiştir.

Tablo 5. Öğretmenlerin Uzaktan Ĕ̆itime Katılamayan Öğrencilere Yönelik Duygu ve Düşünceleri (n=36)

\begin{tabular}{lc} 
Kodlar & (f) \\
Çok üzülüyorum & 27 \\
\hline Kayglanıyorum & 8 \\
\hline Kıgıınım & 4 \\
\hline Çaresiz hissediyorum & 2 \\
\hline Şefkat duyuyorum & 2 \\
\hline Tükenmiş hissediyorum & 1 \\
\hline Suçlu hissediyorum & 1 \\
\hline Stresliyim & 1 \\
\hline Özlüyorum & 1 \\
\hline Belirtilmemiş & \\
\hline
\end{tabular}

*Belirtmeyen öğretmenler arasında yer alan 3 öğretmenin, uzaktan eğitime katılamayan öğrencisi bulunmamaktadır.

Tablo 5’te uzaktan eğitime katıl(a)mayan öğrenciler için hissettikleri duygu ve düşüncelere ilişkin öğretmen görüşleri yer almaktadır. Ortaya çıkan verilere göre öğretmenlerin, uzaktan eğitime katıl(a)mayan öğrenciler için en sık söylenen öğretmen duygu ve düşünceleri olarak "Çok üzülüyorum”, "Kaygılıyım" ve "Kızgınım" ifadelerini belirtmişlerdir. Buna ilişkin olarak Ö1, Ö11 ve Ö21 görüşlerini şu şekilde ifade etmiştir: 
Ö1:

Çok üzülüyorum ve okul başladığında nasıl aynı seviyeye gelecekler diye endişeleniyorum

Ö11:

Temel hakları olan eğitim hakkından mahrum kalmalarına üzülüyorum. Sadece bilgi düzeyi olarak değil arkadaşlık ilişkileri ve sosyalleşmelerinde de gerileme oluyor. Gelecek yıllarda mutlaka bu olumsuzluklar her öğrenciyi farklı șekilde etkileyecek düșüncesindeyim.

Ö21:

Kendilerini dıslanmıs hissetmeleri beni üzüyor (bir ögrencimin annesi evde dort ögrenci var çocuk annesinin bozuk telefonuyla giriyordu dersi takip ediyor anca sesi ve göruntüsü yoktu. Cocugun hıckıriklara bogularak agladigini utana sikıla bana anlatti oglumun tabletini ögrencime verdim.)

Yukarıda da görüldüğü gibi öğretmenlerin genel olarak üzüntü ve kaygı duydukları anlaşlmaktadır. Ö1 ve Ö21, öğrencilerinin uzaktan eğitime katılamayışlarından dolayı üzüntü duyduklarını ifade etmiştir. Ö11 ise öğrencilerin en temel haklardan biri olan eğitim haklarından mahrum kalmalarının yanı sıra öğrencilerin sosyalleşememelerinden dolayı da üzüntülerini ifade etmiştir. Bütün bu durumların da geleceğe kaygı ile bakmalarına sebep olduğunu dile getirmiştir. Görülmektedir ki bazı öğretmenler, öğrencilerin yaşamış olduğu akademik kayıplarla birlikte bir toplumun temel dinamizmi olan çocukların gelecekte yaşayabileceği zorlukları ve bunların sebep olacağı toplumsal etkileri de düşünerek kaygılanmaktadırlar. Aynı zamanda Ö21'in görüşleri incelendiğinde, uzaktan eğitime katılamayan öğrencilerin kendilerini dışlanmış hissetmelerinin öğretmeni derinden etkilediği görülmektedir. Bu duruma çözüm üretmek amacıyla da Ö21 kendi çocuğunun imkanlarından feragat ederek, çocuğunun tabletini öğrencisine hediye etmiştir. Bu örnekte de görüldügü üzere, bazı öğretmenler uzaktan eğitimin meydana getirmiş olduğu olumsuz durumlar karşısında duygusal olarak derinden etkilenmekte ve kendi çözüm yollarını geliştirme çabası içerisinde olmaktadırlar. Aşağıda ise Tablo 6'da uzaktan eğitime katılamayan çocukların velilerinin "Uzaktan eğitim sürecinde çocuğunuzun derslere katıl(a)madığı zamanlarda hissettiğiniz duygu ve düşüncelerinizi detaylarıyla açıklayınız" sorusuna verdikleri yanıtların analiz sonuçlarına yer verilmiştir.

Tablo 6. Velilerin Uzaktan Eğitime Katılamayan Öğrencilere Yönelik Duygu ve Düşünceleri ( $n=18$ )

Kodlar $\quad$ (f)

$\begin{array}{lr}\text { Çok üzülüyorum } & 14\end{array}$

\begin{tabular}{ll} 
Kayglaniyorum & 10 \\
\hline Caresz
\end{tabular}

Caresiz hissediyorum 2

Hassasiyet/Duyarllık 2

Belirtilmemiș ${ }^{*} \quad 1$

*Çocuğu katılamayan yedi velinin yanı sıra diğer 11 velinin, çocukları zaman zaman derslere katılamadıklarında ve uzaktan eğitime katılamayan diğer öğrenciler hakkında hissettikleri duygu ve düşünceler de tabloya dâhil edilmiştir.

Tablo 6'da velilerin uzaktan eğitime katıl(a)mayan çocukları için hissettikleri duygu ve düşüncelere ilişkin görüşleri yer almaktadır. Ortaya çıkan verilere göre velilerin, uzaktan eğitime katıl(a)mayan çocukları için en sık söylenen veli duygu ve düşünceleri olarak "Çok üzülüyorum" ve "Kaygılanıyorum" ifadelerini belirtmişlerdir. Öğretmen ve velilerin duygu ve düşüncelerinin yanı sıra uzaktan eğitim süreci boyunca öğrencilerin uzaktan eğitime erişememeleriyle ilgili olarak şahit oldukları anılara yönelik öğretmenlere "Uzaktan eğitimdeki derslerinize katılımla ilgili yaşadığınız ilginç bir anınızı lütfen detaylarıyla anlatınız” sorusu sorularak elde edilen bulgular aşağıda Tablo 7’de sunulmuştur. 
Tablo 7. Öğretmenlerin Uzaktan Eğitim Sürecinde Derse Katılımla ilgili Yaşadıkları Anılar (n=36)

\begin{tabular}{|c|c|c|}
\hline Tema & Kodlar & (f) \\
\hline \multirow{9}{*}{$\begin{array}{l}\text { Velilerle ilgili olan anılar } \\
\qquad 21\end{array}$} & Velilerin derse/öğretmene müdahalesi & 9 \\
\hline & Öğrencinin uygun ders ortamının oluşturulmaması & 3 \\
\hline & Velilerin uygun olmayan kılık kıyafetle ekranda görülmeleri & 2 \\
\hline & Veli tarafından öğrenciye verilen ekstra sorumluluk & 2 \\
\hline & Velilerin öğretmenden tablet dağıtmalarını beklemeleri & 1 \\
\hline & Velilerin ilgisizliği & 1 \\
\hline & Velilerin canlı dersi önemsememesi & 1 \\
\hline & Maddi yetersizlik & 1 \\
\hline & Derse girmeyi başaran velinin duygulanması & 1 \\
\hline \multirow{4}{*}{$\begin{array}{l}\text { Öğrencilerle ilgili olan anılar } \\
\qquad 11\end{array}$} & Öğrencilerin masum/kurnaz düşünceleri & 4 \\
\hline & $\begin{array}{l}\text { Öğrencilerin derse ilgilerini/motivasyonlarını kaybetmeleri, farklı } \\
\text { davranışlarda bulunmaları }\end{array}$ & 4 \\
\hline & Öğrencinin tüm zorluklara rağmen derse giriş yapması & 2 \\
\hline & $\begin{array}{l}\text { Yüz yüze eğitimde derslere ilgi göstermeyen öğrencinin canlı derslere ilgi } \\
\text { duyması }\end{array}$ & 1 \\
\hline \multirow{2}{*}{$\begin{array}{c}\text { İnternet ve teknolojik donanım } \\
\text { eksikliğinden kaynaklı anılar } \\
6\end{array}$} & İnternet altyapısının yetersizliği & 4 \\
\hline & Tek tabletin kardeşler arasında dönüşümlü kullanılması & 2 \\
\hline \multirow{4}{*}{$\begin{array}{l}\text { Öğretmenlerle ilgili olan anılar } \\
5\end{array}$} & Uzaktan eğitim süreciyle ilgili hizmet içi eğitim yetersizliği & 2 \\
\hline & Öğretmenin güvenli internet önlemlerini almaması & 1 \\
\hline & Öğretmenin eski bir öğrencisinin canlı derse katılması & 1 \\
\hline & Öğretmenin eğitim ortamı yetersizliği & 1 \\
\hline $\begin{array}{c}\text { Anım yok } \\
1\end{array}$ & & 1 \\
\hline
\end{tabular}

Tablo 7’de öğretmenlerin uzaktan eğitim derslerine katılımla ilgili anıları yer almaktadır. Ortaya çıkan verilere göre öğretmenlerin; velilerle, öğrencilerle, teknolojiyle ilgili anılarının olduğu gözlenmektedir. Buna ilişkin olarak Ö1, Ö6, Ö11, Ö14, Ö28 ve Ö35 anılarını şu şekilde ifade etmiştir:

Ö1:

1.sınıfa giden çocuğa annesi bağır diyor.Çocuk bağır diye okudu.

Ö11:

Bir öğrencim mevsimlik işçi olarak Sivas'a patates toplamaya gitmişti. Çadırda kalmasına rağmen canlı dersime katıldı ve tüm zorluklara rağmen ders işledik.

Ö6:

Bağlantısı kesilen öğrencimin derste telefonla arayıp, ağlaması. Benim uzaktan internet verebileceğimi düşünmüş.

Ö14:

Birisi derse girmedi ilk 3 ders.Son 3 derse geldi. Illk dersler nerdeydin dedim. Kızıcaktım.Öğretmenim ablamla dönüşümlü giriyoruz dedi.Tek tablet varmış. Çok üzülmüştüm.Kızmaktan vazgeçip,Tamam kızım gel.Hoşgeldin derse dedim. 
Ö28:

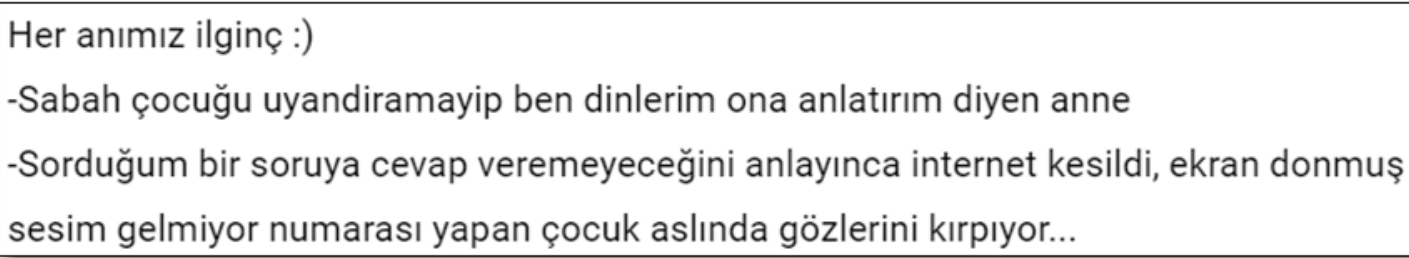

Ö35:

Uzun zaman katılamayan bir öğrenci katılım sağlayınca evde yaşayan
babaanne nin sesimi duyunca sevinçten ağlaması...

Yukarıdaki öğretmen anılardan da görüleceği üzere genellikle üzüntü veren ama zaman zaman komik olarak da görülebilecek yaşantılar gerçekleşmiştir. Velilerin uzaktan eğitim süreci boyunca öğrencilerin uzaktan eğitime erişememeleriyle ilgili olarak şahit oldukları anılarına yönelik "Uzaktan eğitimdeki derslerinize katılımla ilgili yaşadığınız ilginç bir anınızı lütfen detaylarıyla anlatınız" sorusu sorularak elde edilen bulgular aşağıda Tablo 8'de sunulmuştur.

Tablo 8. Velilerin Uzaktan Eğitim Sürecinde Derse Katılımla ilgili Yaşadıkları Anılar ( $n=18)$

\begin{tabular}{|c|c|c|}
\hline Tema & Kodlar & (f) \\
\hline \multirow{3}{*}{$\begin{array}{l}\text { Velilerle ilgili olan anılar } \\
\qquad 11\end{array}$} & Maddi yetersizlik & 6 \\
\hline & Velilerin mikrofonunun açık kalması & 4 \\
\hline & Velilerin derse bağlantıda zorlanması & 1 \\
\hline Öğrencilerle ilgili olan anılar & Öğrencilerin masum/kurnaz duygu ve düşünceleri & 6 \\
\hline \multirow{2}{*}{$\begin{array}{c}\text { İnternet ve donanım eksikliğinden } \\
\text { kaynaklı anılar } \\
5\end{array}$} & İnternet altyapısının yetersizliği & 3 \\
\hline & Tek tabletin kardeşler arasında dönüşümlü kullanılması & 2 \\
\hline $\begin{array}{c}\text { Öğretmenlerle ilgili olan anılar } \\
1\end{array}$ & Öğretmenin süreci yönetmede sıkıntı yaşaması & 1 \\
\hline$\underset{3}{\text { Anım yok }}$ & & 3 \\
\hline
\end{tabular}

Tablo 8'de velilerin uzaktan eğitim derslerine katılımla ilgili anıları yer almaktadır. Ortaya çıkan verilere göre velilerin; öğrencilerle, teknolojiyle ve öğretmenlerle ilgili anılarının olduğu gözlenmektedir. Buna ilişkin olarak V2, V4, V13 ve V16 anılarını şu şekilde ifade etmiştir:

V2:

Derslere bağlanmakta zorluk çekiyordu ilk zamanlarda canlı dersi eba yerine tv'den izleneceğini zannediyordu öğretmenimizin desteği ile canlı derslere katıımı kolaylaştırdık

V4:

cocugum uzun zaman zaten derse giremedi elimizde imkan olmadigi icin bana hissettigi duygulari annattigi zaman. Cocuklarım derse girebilmek icin kendi aralarinda kura cekerek baglaniyor

V13:

Çocuğumun telefon bozulmasın diye dua etmesi 
V16:

Telefondan derse katılıı̆ımız sırada mikrofon açıkmış tabi haberimiz yok oğlum aglıyor anne yanımda kal diye bende tamam dedim anlatıyorum oğluma şunu bunu diye ben sana parmakla gösterdiğim sayıları söyle diye sonra öğretmenimiz seslendi sayın veli lütfen oradan ayrıırmısınız dedi çok utanmışıım

Genel olarak veli anıları incelendiğinde, velilerin büyük bölümünün eğitimin önemine inanmış bir şekilde çocuklarının derslerine katılım sağlamaları için çaba gösterdikleri anlaşılmaktadır. Veliler de bu süreçte belki de daha önce çok da bilmedikleri interneti ve teknolojiyi öğrenme, eve internet bağlama noktasında bilgileri ve maddi güçleri çerçevesinde ellerinden geleni yapmaya çalıştıkları anlaşılmaktadır. Buna karşılık teknolojik araç gereç ve internet yetersizliğinden oluşan durumlar da bir trajediye işaret etmektedir.

\section{Tartışma}

$\mathrm{Bu}$ araştırmada Covid-19 salgını sürecinde gerçekleştirilen uzaktan eğitim faaliyetlerine öğrencilerin katıl(a-) mama durumlarına dair duygu, düşünce ve anılar öğretmen ve velilerin gözünden incelenmiştir. Araştırmada salgın sürecinde gerçekleştirilen etkinlikler, yaşanan sorunlar ve bu sorunlara ilişkin çözüm önerileri incelenmiştir.

Araştırma bulgularına göre öğretmenlerin önemli bir kısmı öğrencilerinin uzaktan eğitime tam katılımın sağlamadığını belirtmişlerdir. Araştırma bulgularına benzer şekilde Yıldız (2020, s. 852) da araştırmasında öğrencilerin uzaktan eğitim ile yürütülen ders ve etkinliklere katılımının düşük olduğunu belirlemiştir. Uzaktan eğitim sürecine her öğrencinin katılamaması öğretmenler tarafından önemli bir sorun olarak görülmektedir. Öğretmenler, öğrencilerin uzaktan eğitime katılamama nedenlerini ise maddi sebepler nedeniyle internet, teknolojik altyapı ve donanım eksikliği, ailenin ilgi göstermemesi, gereken destek ve önemi vermemesi olarak ifade etmişlerdir. Veliler de öğretmenlerle aynı görüşü paylaşarak, teknolojik imkanların yoksunluğu ve kardeş sayısı gibi nedenlerin uzaktan eğitime katılama durumunu olumsuz etkilediğini belirtmişlerdir. Sarı ve Nayır (2020, s. 970) da ailelerin çocuklarının teknoloji ile ilişkilerini sadece sosyal medya ve dijital oyunlarla sınırlı olduklarını ve teknolojik araçları bir eğitim aracı olarak görmedikleri için teminini sağlamadıklarını ifade etmişlerdir. Ailelerin gerek maddi sebeplerden gerekse de uzaktan eğitime ilişkin tutum ve davranışlarından kaynaklı ihtiyaç duyulan teknolojik altyapı ve araç-gereçleri sağla(ya)maması Covid-19 salgını sürecinde yürütülen uzaktan eğitim faaliyetlerini olumsuz etkilemektedir.

Araştırma sonuçlarına göre ailelerin canlı derslere gereken ilgiyi göstermemeleri, önem vermemeleri ya da canlı derse girmede öğrenciye destek olmamaları öğrenci motivasyonunun düşmesine neden olmaktadır. Bu doğrultuda bazı öğrenciler de canlı derslere gereken önemi göstermemekte, canlı derslere girmede isteksiz olmaktadırlar. Öğretmenlerin bu şikayetlerini destekler nitelikte OECD (2020) Covid-19 krizi ile ilgili yayınlamış olduğu araştırmada ailesinden destek alan öğrencilerin uzaktan eğitime yönelik daha fazla olumlu tutum gösterdiklerini ifade etmiştir. Bayburtlu (2020, s. 134) da araştırmasında, velilerin uzaktan eğitime dair tutumlarının öğrencilerin öğrenim süreçlerine katılımında önemli ölçüde etkili olduğunu, özellikle her iki velisi de çalışan öğrencilerin yeterli desteği görmediklerini ve velilerin bu konuda eğitim alması gerektiğini belirlemiştir. Benzer şekilde Çakın ve Külekçi Akyavuz (2020, s. 171) araştırmalarında Covid-19 sürecinde yürütülen eğitim faaliyetlerinde öğretmenler tarafından en sık dile getirilen sorunun veli desteğinin olmayışı ifade edilmiştir. Aile desteği özellikle ilkokul döneminde çocukların öğrenmelerinin sorumluluğunu üstlenme ve bağımsız çalışabilme becerilerini edinene kadar geçen süreçte kritik öneme sahiptir. Ancak hem gerçekleştirilen bu araştırmanın bulgularında hem de alan yazındaki ilgili çalışmalarda bu öğrencilerin yeterli desteği göremedikleri anlaşılmaktadır.

Araştırma bulgularının çevrimiçi anket ile toplanan verilerinin ardından iki ay geçmesinden sonra yüz yüze görüşmeler yoluyla elde edilen verilerde de maddi sebeplerden dolayı yaşanan eksikliğin giderilmesine rağmen derslere katılmama sorununun halen sürdüğü, bunun nedenlerine ilişkin, özellikle ailesinde Covid-19 hastalığına yakalananların olduğu öğrencilerde görülen motivasyon kaybı ve okula olan bağın zayıflaması olarak belirlenmiştir. Öğretmen ve veli görüşlerine göre maddi kaynaklı nedenlerin bir kısmı, EBA destek noktalarından faydalanılarak, komşulardan destek alınarak veya gerekli teknolojik araç gereç temin edilerek çözülmeye çalışılmıştır. Ancak velilerin ilgi ve tutumlarının öğrencilerin eğitim hayatlarına olumsuz yansımaları halen devam etmektedir. Bu noktada Millî Eğitim Bakanlığının gerekli tedbirleri alması gerektiği açıç̧a görülmektedir. Velilerin gerek okullarda bulunan rehber öğretmenler gerekse de gerçekleştirilecek olan seminerler aracılığı ile bilinçlendirilmesinin sağlanması gerekmektedir. Sarı ve Nayır (2020, s. 972) da UNESCO, OECD ve Dünya Bankası’nın Covid-19 ile ilgili yayımladığı raporları inceledikleri araştırmalarında, eğitim sürecine veli katılımının artırılmasının ve velilerin işleyiş hakkında 
bilinçlenmelerinin evde eğitim sürecine katkı sağlayacağını belirtmişlerdir. Ayrıca yurtdışında yapılan uzaktan eğitimle ilgili uluslararası araştırmalar incelendiğinde öğretmenlerin teknolojik açıdan kısıtlamalara maruz kaldığı (Hilli, 2020) ve eğitimde fırsat eşitliği konusunda geliştirilmelere ihtiyaç duyulduğu (Sargrad ve ark., 2020, s. 1) ifade edilmiştir.

Öğretmenler salgın sürecinde gerçekleştirilen uzaktan eğitim uygulamalarına katılamayan öğrencilere yönelik geliştirilebilecek çözüm önerilerini devletten, aileden, öğretmenlerden ve toplumdan olmak üzere dört tema altında belirtmişlerdir. Öğretmenler, devletin öğrenci ve ailelere, internet, teknolojik donanım ve altyapı desteği sağlaması, öğrencinin uzaktan eğitime katılımında yaptırım uygulaması gerektiğini düşünmektedir. Benzer şekilde öğretmen görüşleri alınan bazı çalışmalarda, salgın döneminde derse katılım zorunluluğu olması (Yıldız, 2020, s. 851), öğrencilerin internet, dijital altyapı ve iletişim aracı eksikliklerinin giderilmesi (Çakın ve Külekçi Akyavuz, 2020, s. 181; Sarı ve Nayır, 2020, s. 962) gerektiğine ulaşılmıştır. Ailelerinin sosyo-ekonomik nedenlerden dolayı gerekli teknolojik araç-gereçleri karşılayamaması, öğretmenlerde bu ihtiyaçların devlet tarafından karşılanma beklentisini oluşturduğu anlaşılmaktadır. Uzaktan eğitim, eğitim teknolojilerinin kullanılmasıyla fırsat eşitliğini ön planda tutan, bireysel çalışma ve öğrenmeye imkân tanıyan bir model (Kaya, 2002, s. 19-20) olmasına rağmen teknolojiye erişimde yaşanan eşitsizlikler fırsat eşitsizliğinin belirgin hale gelmesine neden olmaktadır (Sezgin ve Fırat, 2020, s. 38). Öğrenci ve ailelerin aynı ekonomik şartlara ve gerekli teknolojik donanıma sahip olmaması, eğitimde mevcut bulunan fırsat eşitsizliğini uzaktan eğitim sürecinde daha da derinleştirmektedir. Bununla birlikte öğretmenler ailelerin bu süreçte öğrencinin derslerine karşı ilgili olması, farkındalık sağlaması ve bilinçlenmesi gerektiğini söylemişlerdir. Veliler, destek ve ilgileriyle çocuklarının eğitim hayatına etkili bir şekilde yön veren konumdadır (Çakın ve Külekçi Akyavuz, 2020, s. 180). Uzaktan eğitim sürecinde de öğretmenlerin, öğrencileri yanındaki en büyük destekçisi kuşkusuz velileridir. Bu süreçte ailesinin destek ve ilgisini gören öğrencilerin de öğrenmeye karşı daha ilgili ve pozitif tutum sergiledikleri görülmektedir (OECD, 2020; Yıldız, 2020, s. 848). Öğrencilerin bilişsel ve kişisel gelişimlerinde oldukça önemli konumda olmalarına rağmen veli desteğinin ve ilgisinin yetersiz olması, bu süreçte öğretmen desteklerini de sınırlamaktadır. Öğretmenler toplumdan ise çeşitli sosyal sorumluluk projeleriyle derslere katılamayan öğrencilere destek olunmasını beklediklerini belirtmişlerdir. Bu durum, eğitimde fırsat eşitsizliğinin toplumsal bir sorun olduğunu, toplumun da bu sorunun çözümü için görev alması gerektiğini düşündürmektedir.

Öğretmenler diğer eğitim paydaşlarından sorunların çözümü için beklentilerinin yanı sıra bireysel olarak sorunların giderilmesi için de çaba harcadıklarını ifade etmişlerdir. En sık başvurdukları çözüm yollarını ise öğrencilerle iletişim halinde olmak, telefonla ders anlatmak ve ödev vermek olarak ifade etmişlerdir. Elde edilen verilere göre, öğretmenlerin büyük bir kısmının öğrencilerine telafi edici çalışmalarla destek olmak için çaba harcadığ 1 anlaşılmaktadır. Bununla birlikte öğretmenler yardımcı kaynak kitaplardan yararlandıklarını, öğrencilere video çekip gönderdiklerini ve öğrencilerin EBA platformlarından yararlanmaları için teşvik edici olduklarını belirtmişlerdir. Teknolojik donanım ve altyapı eksiği yaşayan öğrenci ve ailelere çözüm olarak yine teknolojik araçların gösterilmesi de dikkat çekicidir. Bu çabaların yanında ders saatleri dışında ek ders yapan öğretmenlerin de bulunması, öğretmenlerin fedakâr olduklarını ve hassas davrandıklarını göstermektedir. Telafi edici çalışmalar yapamayan öğretmenler ise veli-öğrenci ilgisizliği ve internet erişiminin yetersizliğini neden olarak belirtmişlerdir. Sorunların çözümlerine ilişkin gösterilen tüm bu çaba ve önerilere rağmen bazı öğretmenler gerçekleștirilecek olan uygulamaların kesin bir çözüm olmayacağını ve en iyi çözüm yolunun yüz yüze eğitimin başlaması olduğunu belirtmişlerdir.

Öğretmen ve veliler, uzaktan eğitim sürecinde hissettikleri duyguları ise üzüntü, kaygı, kızgınlık, çaresizlik, şefkat, tükenmiş, suçlu ve stres olarak ifade etmişlerdir. Öğretmenlerin derslere katılamayan öğrencilerinin eğitim haklarından mahrum kalmaları, kendilerini dışlanmış hissetmeleri ve arkadaşlarıyla iletişim kuramamaları nedeniyle duydukları derin üzüntülerine çare bulmak için kendi çözüm yollarını geliştirme çabası içerisine girmişlerdir. Benzer şekilde bazı araştırmalarda da, öğretmenlerin ve öğrencilerin uzaktan eğitim sürecinde sosyalleşememe/yalnız kalma (Sirem ve Baş, 2020, s. 1006) ve uzaktan eğitim sürecinde kendilerini yetersiz hissetme (Bakioğlu ve Çevik, 2020, s. 126) gibi durumlardan dolayı üzüntü duydukları görülmektedir. Bu süreçte öğretmen ve veliler özveri ile öğrencilerin derslere erişimi için gayret gösterdiklerine dair anı ve yaşantılardan bahsetmişlerdir. Aynı zamanda süreçte hem trajik hem de trajikomik durumların yaşandığı tespit edilmiştir. Öğretmen ve velilerin uzaktan eğitim sürecinde yaşadıkları anıların genel olarak velilerin derslere müdahalesi, velilerin mikrofonunun açık kalması, öğrencilere uygun ders ortamının oluşturulamaması, internet-altyapı yetersizliği, derse bağlanmakta zorlanma, tek tabletin kardeşler arasında dönüşümlü kullanılması, öğretmenlerin uzaktan eğitim süreciyle ilgili hizmet içi eğitim yetersizliği ve süreci yönetmede sıkıntılar yaşaması, öğrencilerin masum-kurnaz düşünceleri ve derse ilgilerini, motivasyonlarını kaybetmeleri ve farklı davranışlarda bulunmalarıyla ilgili olduğu görülmektedir. 


\section{Sonuç}

Öğretmenlerin önemli bir kısmı uzaktan eğitim sürecinde öğrenci katılımlarının düşük olduğunu belirtmiştir. Öğretmenlere göre; uzaktan eğitim sürecinde öğrenciler internet, teknolojik altyapı ve donanım eksikliği, ailelerin ilgisizliği, derslere girme konusunda destek ve gereken önemi vermemeleri, yeterli bilgi/eğitime sahip olmamaları nedeniyle derslere katılamamaktadır. Velilere göre ise; öğrenciler, internet, teknolojik altyapı/donanım eksikliği ve kardeş sayısı gibi nedenlerle derslere katılmakta zorlanmaktadırlar.

Öğretmenler uzaktan eğitime katılamayan öğrenciler için devletten internet, teknolojik donanım-altyapı desteğini sağlaması ve uzaktan eğitime devam konusunda yaptırım uygulaması gerektiğini; ailelerden, çocuklarının derslerine karşı ilgili olmalarını, farkındalık sağlamalarını ve canlı derslere yönelik bilinçlenmelerini beklemektedirler. Öğretmen olarak çocuklara verecekleri ödevlerle akademik anlamda destek olabileceklerini, iletişim halinde kalarak ise motive edebilecekleri düşünmektedirler. Toplumun ise teknolojik araç-gereç yoksunluğu yaşayan öğrenciler için sosyal sorumluluk projeleri düzenleyerek destek olabileceğini belirtmişlerdir. Öğretmenler, öğrencilerine bu süreçte sosyal iletişim uygulamaları üzerinden, çalışma sayfaları göndererek ve yardımcı kaynak kitaplardan ödevlendirmeler yapmaktadırlar. Bu çalışmaların dışında öğretmenler; öğrencilerini video göndermek, telefonla ders anlatmak, EBA platformlarına yönlendirmek ve ek canlı dersler yapmak gibi çalışmalarla da desteklemektedirler. İnternete erişimin sınırlı olması, velilerin canlı dersleri önemsiz görmesi ve öğrencilerin derslere ilgisizliği gibi nedenlerle de bazı öğretmenler telafi edici çalışmalar dahi yapamamaktadır.

Öğretmenler, uzaktan eğitim sürecinde derslere katılamayan öğrencilere yönelik kendilerini üzgün, kaygıll, kızgın ve çaresiz hissetmektedirler. Tüm bu duyguların yanında tükenmiş, suçlu ve stresli hisseden öğretmenler de mevcuttur. Öğretmenlerin derslere katılamayan öğrencilerinin eğitim haklarından mahrum kalmaları, kendilerini dışlanmış hissetmeleri ve arkadaşlarıyla iletişim kuramamaları nedeniyle derin üzüntüler yaşadıklarını, bu durum karşısında kendi çözüm yollarını geliştirme çabası içinde oldukları görülmektedir. Uzaktan eğitime katılamayan öğrencilerin velileri de öğretmenlere benzer şekilde kendilerini üzgün, kaygılı ve çaresiz hissetmektedirler.

Öğretmen ve velilerden toplanan verilerde bazıöğrencilerin mevsimlik işçi olarakçalıştıkları için patates tarlalarında, bazı öğrencilerin ancak merdiven boşluğunda çeken komşularının internetinden faydalanarak zor şartlar altında da derslere katıldıkları, bazı öğrencilerin ise tüm çabalarına rağmen derslere katılamadıkları tespit edilmiştir. Bu durum uzaktan eğitim sürecinden önce de mevcut bulunan firsat eşitsizliğinin uzaktan eğitimle birlikte daha belirgin bir hale geldiğini göstermektedir. Öğretmen ve velilerin uzaktan eğitim sürecinde yaşadıkları anıların genel olarak velilerin derslere müdahalesi, velilerin mikrofonunun açık kalması, öğrencilere uygun ders ortamının oluşturulamaması, internet-altyapı yetersizliği, derse bağlanmakta zorlanma, tek tabletin kardeşler arasında dönüşümlü kullanılması, öğretmenlerin uzaktan eğitim süreciyle ilgili hizmet içi eğitim yetersizliği ve süreci yönetmede sıkıntılar yaşaması, öğrencilerin masum-kurnaz düşünceleri ve derse ilgilerini, motivasyonlarını kaybetmeleri ve farklı davranışlarda bulunmalarıyla ilgili olduğu görülmektedir.

\section{Öneriler}

- Covid-19 salgını sürecinde gerçekleştirilen uzaktan eğitim faaliyetlerinde karşılaşılan sorunlar ve bu sorunlara yönelik çözüm önerilerinin ortaya konmasının amaçlandığı bu araştırmada elde edilen sonuçlar kapsamında aşağıdaki öneriler geliştirilmiş.

- Tüm öğrencilere canlı derslerde kullanması için ücretsiz ve sınırsız internet desteği sağlanabilir.

- Velilerin bilinçlenmesi ve bilgilendirilmesi için seminer, eğitim ve çalışmalar arttırılarak yaygınlaştırılabilir.

- Öğrencilerin öğrendiklerini pekiştirmeleri için ilkokul kademesine yönelik EBA gibi platformların içeriği zenginleştirebilir.

- Gerekli teknolojik araç-gereçleri temin etmede güçlük çeken öğrenciler için sosyal sorumluluk projeleri gerçekleştirilebilir.

- Gelecek araştırmalarda farklı bölgelerde yaşayan öğretmen, öğrenci ve velilerle yüz yüze görüşmeler ve sınıf gözlemleri yapılabilir. 


\section{KAYNAKÇA}

Bakioğlu, B. ve Çevik, M. (2020). Covid-19 pandemisi sürecinde fen bilimleri öğretmenlerinin uzaktan eğitime ilişkin görüşleri. Electronic Turkish Studies, 15(4). http://dx.doi.org/10.7827/TurkishStudies.43502

Başaran, M., Doğan, E., Karaoğlu, E. ve Şahin, E. (2020). Koronavirüs (covid-19) pandemi sürecinin getirisi olan uzaktan eğitimin etkililiği üzerine bir çalışma. Academia Eğitim Araştırmaları Dergisi, 5(2), 368-397. https:/dergipark.org.tr/tr/download/ article-file/1152012 adresinden erişildi.

Bayburtlu, Y. S. (2020). Covid-19 Pandemi dönemi uzaktan eğitim sürecinde öğretmen görüşlerine göre Türkçe eğitimi. Electronic Turkish Studies, 15(4). doi: http://dx.doi.org/10.7827/TurkishStudies.44460

Bozkurt, A. (2020). Koronavirüs (covid-19) pandemi süreci ve pandemi sonrası dünyada eğitime yönelik değerlendirmeler: yeni normal ve yeni eğitim paradigması. Açıköğretim Uygulamaları ve Araştırmaları Dergisi, 6(3), 112-142. https://dergipark.org. tr/en/download/article-file/1215818 adresinden erişildi.

Büyüköztürk, Ş., Kılıç Çakmak, E., Akgün, Ö. E., Karadeniz, Ș. ve Demirel, F. (2015). Bilimsel Araștırma Yöntemleri. (19.Basım). Ankara: Pegem Akademi Yayınları.

Çakın, M. ve Külekçi Akyavuz, E. (2020). Covid-19 süreci ve eğitime yansıması: öğretmen görüşlerinin incelenmesi. International Journal of Social Sciences and Education Research, 6(2), 165-186. doi: https://doi.org/10.24289/ijsser.747901

Doğan, S. ve Koçak, E. (2020). Eba sistemi bağlamında uzaktan eğitim faaliyetleri üzerine bir inceleme. Ekonomi ve Sosyal Araştırmalar Dergisi, 7(14), 111-124. http://www.ekosad.net/FileUpload/ep939088/File/42_soner_dogan.pdf adresinden erişildi.

Fidan, M. (2020). Covid-19 belirsizliğinde eğitim: ilkokulda zorunlu uzaktan eğitime ilişkin öğretmen görüşleri. Uşak Üniversitesi Eğitim Araştırmaları Dergisi, 6(2), 24-43. doi:10.29065/usakead.736643

Hilli, C. (2020). Distance teaching in small rural primary schools: a participatory action research project. Educational Action Research, 28(1), 38-52. doi: 10.1080/09650.792.2018.1526695

Kaya, Z. (2002). Uzaktan Eğitim. (1.baskı). Ankara: Pegem Akademi Yayınları.

Milli Eğitim Bakanlığı (2020). Türkiye uzaktan eğitim istatistikleriyle dijital dünyanın listelerini zorladı. http://meb.ai/frkHEn adresinden erişildi.

Milli Eğitim Bakanlığı. (2021). EBA, 1.2 milyar tıklanma sayısıly kendi rekorunu güncelledi. https://www.meb.gov.tr/eba-12milyar-tiklanma-sayisiyla-kendi-rekorunu-guncelledi/haber/20862/tr adresinden erişildi.

Miles, M. B. ve Huberman, A. M. (1994). Qualitative data analysis: An expanded sourcebook. (2. basim). Thousand Oaks: Sage.

OECD. (2020). Strengthening online learning when schools are closed: The role of families and teachers in supporting students during the COVID-19 crisis 02.02.2021 tarihinde https://read.oecd-ilibrary.org/view/?ref=136_136615 o13x4bkowa\&title=Strengthening-online-learning-when-schools-are-closed adresinden erişildi.

Özer, M. ve Suna, H. E. (2020). Covid-19 salgını ve eğitim. Küresel Toplumun Anatomisi: İnsan ve Toplumun Geleceği, 171-192. http://www.tuba.gov.tr/tr/yayinlar/suresiz-yayinlar/bilim-ve-dusun/kuresel-salginin-anatomisi-insan-ve-toplumungelecegi adresinden erişildi.

Sargrad, S., Harris, K. M., Partelow, L., Campbell, N. ve Jimenez, L. (2020). A First 100 Days Agenda for K-12 Education. Center for American Progress. 1-14.

Sarı, T. ve Nayır, F. (2020). Pandemi dönemi eğitim: sorunlar ve firsatlar. Electronic Turkish Studies, 15(4). doi: https://dx.doi. org/10.7827/TurkishStudies.44335

Sezgin, S. ve Fırat, M. (2020). Covid-19 pandemisinde uzaktan eğitime geçiş ve dijital uçurum tehlikesi. Açıköğretim Uygulamaları ve Araştırmaları Dergisi, 6(4), 37-54 https://dergipark.org.tr/en/ download/article-file/1195678 adresinden erişildi.

Sirem, Ö. ve Baş, Ö. (2020). Okuma güçlüğü olan ilkokul öğrencilerinin covid-19 sürecinde uzaktan eğitim deneyimleri. Electronic Turkish Studies, 15(4). doi: http://dx.doi.org/10.7827/TurkishStudies.43346

T.C. Sağlık Bakanlığı. (2020). Covid-19 sözlüğü. https://covid19.saglik.gov.tr/TR-66494/pandemi.html adresinden erişildi.

TEDMEM. (2020). Covid-19 sürecinde eğitim: uzaktan öğrenme, sorunlar ve çözüm önerileri. https://tedmem.org/yayin/covid19-surecinde-egitim-uzaktan-ogrenme-sorunlar-cozum-onerileri adresinden erişildi.

Türk Tabipler Birliği. (2020). Covid-19 pandemisi ve derinleşen eğitim eşitsizlikleri. https://www.ttb.org.tr/kutuphane/covid19rapor_6/covid19-rapor_6_Part64.pdf adresinden erişildi.

United Nations Educational, Scientific and Cultural Organization. (2020a). 826 milyon öğrencinin evinde bilgisayar yok. https:// 
tr.euronews.com/2020/04/21/unesco-826-milyon-ogrencinin-evinde-bilgisayar-yok adresinden erişildi.

United Nations Educational, Scientific and Cultural Organization. (2020b). COVID-19 Education Response. How many students are at risk of not returning to school? https://unesdoc.unesco.org/ark:/48223/pf000.037.3992 adresinden erişildi.

United Nations International Children's Emergency Fund. (2020). UNICEF tarafından yayınlanan yeni rapora göre, dünyadaki çocukların en az üçte biri, Koronavirüs salgını nedeniyle okulların kapanmasının ardından uygulanan uzaktan eğitime erişim sağlayamıyor. https://tek.link/unicef adresinden erişildi.

World Health Organisation. (2021). WHO Director-General's statement on IHR Emergency Committee on Novel Coronavirus (2019-nCoV). https://covid19.who.int/ adresinden erişildi.

Yıldırım, A. ve Şimşek, H. (2018). Sosyal Bilimlerde Nitel Araştırma Yöntemleri. Ankara: Seçkin Yayıncılık.

Yıldız, V. A. (2020). Covid-19 salgın dönemi uzaktan eğitim sürecine ilişkin öğretmen ve veli görüşlerinin incelenmesi. International Symposium of Educationand Values-4, 841-854. https://www.researchgate.net/publication/348167297 adresinden erişildi. 


\title{
The Stories of Students' Participation in Distance Education from the Perspective of Teachers and Parents: "Distance Education or Distant Education?"
}

\author{
Yücel KABAPINAR (D), Büşra Melis KANYILMAZ (D), Nihan ÖREN KOÇHAN (iD, Uğur ATiK (D)
}

\section{The aim of the study}

In this study, it was aimed to evaluate students' opinions about the reasons why they could not participate in the distance education process during the Covid-19 epidemic and the situations that teachers and parents witnessed during the process from the eyes of classroom teachers and parents. In this context, the questions of the research are as follows:

1. What are the reasons for students not / not able to participating in distance education according to the opinions of teachers and parents?

2. What are the perspectives of teachers and parents regarding the solutions developed for students who do not/ able to participate in distance education?

3. What are the feelings, thoughts and memories of teachers and parents about distance education?

\section{Problem Status}

The Covid-19 epidemic, which affected the whole world, negatively affected all areas of human life. One of these areas is education. As in many countries, studies have been carried out in our country to reduce the negative effects of the epidemic in this process, and distance education applications have been implemented in order to find solutions to the problems in education. Turkey closed schools on March 16, 2020, and since March 23, 2020 distance education was started with classes in all levels. In this process, it has been tried to continue distance education through internet applications established by schools themselves, Information Technologies Network in Education (EBA), TRT EBA TV and various applications that provide video and audio participation on the internet.

The benefits and limitations of distance education applications, which are on the agenda of countries due to the Covid-19 disease, have also started to be discussed. Besides the benefits of distance education, there are also some limitations. These; limitations such as preventing students from socializing, difficulty of students who do not have the habit of self-learning, being dependent on transportation and access opportunities (Kaya, 2002), difficulty in communicating remotely (Hilli, 2020). The sudden start of distance education in our country has caused some problems. Mainly, students' access to live lessons, lack of technological tools and equipment, and educational environments in the home show that distance education should be discussed in terms of equality (Bozkurt, 2020; Özer \& Suna, 2020, p. 363).

Identifying the problems experienced in the distance education process is a big step towards the solution of these problems. Suggestions from teachers, students and parents, who are among the most important education stakeholders, are also a part of this step. The results of the research are important as it is thought that they can shed light on the education process in the Covid-19 epidemic period and can guide for future studies. 


\section{Method}

The research is a qualitative research and has a single case pattern that is intertwined. The study group of the study consists of 36 classroom teachers working in primary schools and teaching in distance education in the 2020-2021 academic year, and 18 parents with children studying at primary school level. Online survey form and semi-structured interview form were used to collect research data. First of all, participant classroom teachers and parents filled out the online questionnaire prepared by the researchers. Then, interviews were conducted with three teachers selected from among 18 participant parents and three teachers selected from 36 participant teachers. The obtained data were analyzed using content analysis. In this study Miles and Huberman's analysis model was used for the reliability of the study and the reliability value was calculated as 0.88 .

\section{Conclusion and Suggestions}

According to the results of the research, a significant part of the teachers stated that there is no full participation in their classrooms and that students have problems in attending live lessons. Teachers stated that, apart from socio-economic reasons, there are also factors stemming from parents, students and teachers in students' inability to participate in the distance education process. Teachers; They stated that students mostly could not participate due to problems such as internet access problems, lack of technological infrastructure and equipment, families not showing interest, not giving support and importance, and families not having enough education. Parents, on the other hand, attribute the distance education participation problems of students to material reasons such as internet, technological infrastructure, lack of equipment and number of siblings. It has been determined that teachers commonly assign homework social communication applications and auxiliary sources for students who cannot participate in distance education and also shoot and send videos, and teach by phone. For students who cannot participate in the distance education process, the feelings and thoughts of classroom teachers and parents are similar. Teachers and parents stated that they mostly felt sorry, anxious and helpless about the process. Classroom teachers need parents to be interested and aware of students who cannot participate in distance education; they expect internet, technological equipment and infrastructure support from the state. It has been observed that there are a limited number of studies on the effectiveness and success of distance education. It has been suggested that future studies can be handled in different dimensions.

Bu makaleye atıf yapmak için / To cite this article:

Kabapınar, Y., Kanyılmaz, B.M., Ören Koçhan, N. \& Atik, U. (2021). Öğretmen ve Velilerin Gözünden Öğrencilerin Uzaktan Eğitime Katılımlarının Öyküleri: “Uzaktan Eğitim mi, Uzakta Kalan Eğitim mi?". Temel Eğitim Araştırmaları Dergisi, 1(1): 79-98. doi: 10.29228/mutead.6 